\title{
POSSIBILIDADES PARA A TRANSNACIONALIDADE DEMOCRÁTICA
}

\author{
Arnaldo Miglino \\ Paulo Márcio Cruz
}

\section{RESUMO}

O presente artigo aborda o modelo atual de Democracia e sua insuficiência para enfrentar os novos ambientes assimétricos das sociedades complexas de risco, considerando o caráter assimétrico de sua representatividade e, como é urgente, uma reavaliação dos seus atuais modelos, para que atendam de maneira adequada a atuais demandas por participação. As hipóteses deste artigo se estribam na premissa de que a autêntica participação só pode ser alcançada quando todos se sentem espiritualmente participantes.

Palavras-chave: Democracia Assimétrica. Democracia Participativa. Democracia Representativa. Estado Constitucional Moderno. Globalização.

\section{INTRODUÇÃO}

Antes de se rediscutir a Democracia, agora em termos transnacionais, é necessário refletir sobre o fato de que, como disse Bobbio, mesmo em relação aos Estados nacionais, a mesma não tenha mantido as suas promessas sobre a efetiva participação do povo no governo e sobre a igualdade, não apenas formal, mas também substancial. ${ }^{3} \mathrm{~A}$ Democracia não conseguiu cumprir suas promessas porque foi realizada, principalmente, (com algumas exceções nos países do norte europeu) como processo no qual são respeitadas, fundamentalmente, as liberdades negativas que excluem a ingerência do Estado no ambiente privado do cidadão.

Por esse motivo a Democracia Direta de certa forma sempre questionou a Democracia Representativa por perguntar o que e quem é representado. É a primeira pergunta que se deve fazer sobre a representação dos interesses gerais dos indivíduos, quando uma representação razoável deveria expressar, de modo mais ajustado e funcional, a soma não indiferenciada de seus interesses concretos. ${ }^{4} \mathrm{O}$ mundo complexo da globalização e as sociedades cada vez mais heterogêneas praticamente reduz a democracia a mero procedimento ${ }^{5}$. Em segundo lugar, deve-se criticar o fato de que os representantes exerçam uma representação livre ou independente de seus representados, no duplo sentido de não estar vinculado ao mandato destes nem sujeitos, salvo algumas raras exceções, à possibilidade de serem revogados ou substituídos em qualquer momento que os representados o decidam. O mandato é quase intocável, salvo casos excepcionais, dentro da lógica do Estado Constitucional Moderno.

Por outro lado, é preciso perguntar se uma Democracia Direta constituiria, como único tipo de regime de governo, uma proposta sensata e sem ser contraproducente. A participação de todos os indivíduos, em todas as decisões, não seria humanamente desejável, pois nem tudo é político, como escreve 
Bilbeny ${ }^{6}$. Não é o adequado nem pelo ponto de vista democrático. É fácil prever que gere, ao final, o desinteresse pela política, a apatia. Nem a própria Internet eliminaria alguns destes obstáculos.

Por sua vez, a Democracia Representativa vem tendo que enfrentar, como se sabe, sociedades muito complexas, com forte divisão de classes e demandas sociais cada vez maiores e mais variadas. Este fato tem se traduzido numa representação excessivamente genérica e na adoção da figura do representante fiduciário, ou seja, sem caráter revogável. É dizer, a Democracia Representativa transformou-se numa Democracia Parlamentar, só um procedimento, e não um valor que possa representar as expectativas atuais.

Foi como reação ao terror patrocinado pela Revolução Francesa que Benjamin Constant opôs a Democracia dos homens antigos, expressada pelo exercício de uma soberania política que encontrava cumprimento na participação na vida da cidade - a mesma soberania em cujo nome a Revolução Francesa cometeu algumas atrocidades -, à Democracia própria dos homens modernos, dos indivíduos, expressando que qualquer construção política deve ter, como primeiro objetivo, protegê-los dentro de certos limites, compatíveis com o exercício desta mesma liberdade por parte de outros indivíduos. A Sociedade não seria mais que a humilde servidora de indivíduos igualmente livres e dotados de razão.

A história dos últimos dois séculos é, em boa medida, a história do enfrentamento entre estas duas concepções de Democracia e das infrutíferas tentativas para conciliá-las. Socialistas utópicos, nacionalistas, militantes da descolonização, todos tiveram a mesma fé na Democracia própria dos homens antigos, a única capaz de fundar, como acreditavam, uma verdadeira comunidade humana. Os antigos haviam compreendido em que consiste uma força mobilizadora posta a serviço de um ideal. Eles nunca aceitaram que a mera busca individual da felicidade bastasse para explicar e, muito menos, fundar uma Sociedade, nem que a mão invisível da razão pudesse regular as relações políticas do mesmo modo que ajusta os mercados. Entre o posterior equilíbrio resultante da relação entre oferta e demanda e a vontade geral de uma comunidade política, não pode existir compromisso. E todos que rechaçavam esta confusão entre economia e política não admitiam que se pudesse reduzir a política a uma simples técnica de organização das relações entre os indivíduos. A abstração do indivíduo, operada pelos economistas - antes de qualquer coisa um consumidor/intervencionista, e só depois cidadão - opuseram as realidades concretas das relações de classe ou de pertencer a uma nação. As sociedades humanas não são apenas uma série de agrupamentos funcionais destinados a conseguir a maximização por parte de cada indivíduo de sua "utilidade marginal". Seriam como campos de força que se encontram em perpétua luta, tanto interna como externa, nos quais os mais fortes tentam esmagar os mais fracos e as relações sociais se definem pela luta de classes. ${ }^{7}$ Os indivíduos não existiriam à margem do contexto social e histórico dentro do qual se organizam suas vidas.

Entre outras questões, a dicotomia entre estas duas formas de entender a democracia corresponde, diretamente, a duas maneiras de conceber a natureza humana. O que se procura mostrar neste trabalho é que um mundo menos baseado na territorialidade, menos fundado nas contingências da história e da 
geografia e mais afinado com as possibilidades de difusão do poder, não significa o desaparecimento completo da Democracia própria dos antigos, mas sim sua adaptação aos novos tempos, a uma civilização progressivamente mais empática. Essa fé no indivíduo que, desde o renascimento, confere seu dinamismo ao mundo, não põe fim à necessidade de pertencer a alguma comunidade humana. $O$ processo gradual que vai das comunidades por herança, que nos são impostas pela evidência da história e da geografia, às comunidades por opção, deverá renovar essa concepção política no lugar de eliminá-la. Ao mesmo tempo mostra a necessidade de se existir dentro da comunidade e, portanto, de não renunciar à Democracia dos antigos, mas também mostra o caráter contingente e problemático de qualquer comunidade humana - o que é atributo da Democracia dos modernos que deveria impedir que se entregue por completo a determinadas formas de comunidade que poderiam dar a impressão de criar comunidades naturais. Por outro lado este processo não é linear, pois dependerá da comunidade a qual se considera vinculado o indivíduo. Às comunidades tradicionais, como a cidade ou o Estado Constitucional Moderno, nas quais hoje a capacidade de opção do indivíduo não só se mantêm, mas se amplia, são somadas novas comunidades das quais é mais difícil se desvincular, como é o caso das realidades regionais, fruto dos processos de integração, ou simplesmente, de impossível persecução, como é o caso da comunidade mundial ou global. ${ }^{8}$ A construção política das comunidades regionais e da comunidade planetária obrigará a se buscar fórmulas de implementação dos princípios democráticos que necessariamente não poderão ser idênticos aos que serviram para as comunidades tradicionais, o que dará lugar inexoravelmente a modelos de democracia assimétrica. Sem dúvidas, em comunidades avançadas e relativamente reduzidas, como cidades ou, no limite, Estados nacionais, as novas tecnologias farão possível a introdução de mecanismos de democracia participativa, e inclusive direta, que alterem substancialmente os procedimentos democráticos atuais. Por outro lado, nas esferas regionais e, sobretudo, no espaço global, a democracia participativa é, hoje, inviável e até a sacrossanta regra "um homem, um voto", apresenta dificuldades insolúveis, não só em aspectos técnicos, mas também a própria dificuldade de conseguir, por esta via, a defesa dos interesses coletivos referentes à vida no Planeta.

Assim, o caminho que se abre para a Democracia no Século XXI é bastante estreito, apesar de longo. A globalização obriga a recuperar a reflexão sobre a Democracia dos modernos e a se perguntar pelas questões de seus fundamentos, as instituições que garantem seu exercício e seus limites $^{9}$ em contextos sociais diferentes.

Entre a vontade universalista, mas apolítica, do mercado, fundada sobre a ilusão de um indivíduo universal e abstrato que seria tomado como referência absoluta e a experiência política das comunidades particulares às quais pertencem os cidadãos, faz-se urgente encontrar construções políticas adequadas e que possam evitar essa falta de intermediação política, que coloca a todos cara a cara, de forma insuportável, com a globalização. ${ }^{10} \mathrm{O}$ desafio é, pois, politizar a globalização para que seus espontâneos processos econômicos e sociais constituam um progresso civilizatório e não se convertam em barbárie. O que denominamos de "republicanização da globalização"11. 
Em que contexto debate-se, hoje, a questão da Democracia nos países ocidentais e no mundo, questiona Santos ${ }^{12}$. Pode-se perguntar em que situação esses países se encontram. O que caracteriza a Sociedade Moderna é que, nela, existe uma discrepância interessante entre as experiências que vivemos e as experiências que temos. As sociedades antigas eram simétricas entre experiência e expectativas: o que nascia pobre morria pobre. Ao contrário, a Sociedade moderna tentou superar esta discrepância. Em suma, a Sociedade Moderna acena com esperança.

O problema é que hoje vivemos um tempo em que, para a grande maioria da população mundial, esta discrepância se inverteu. As experiências atuais são, provavelmente, muito difíceis, mas as expectativas são ainda piores ${ }^{13}$. Ou seja, a idéia de que se houver uma reforma do sistema de saúde, da previdência social ou da educação, não é para melhorar, mas para piorar.

Atualmente temos um colapso total das expectativas: quem come hoje não sabe se comerá amanhã. Quem paga universidade para seu filho este ano, não sabe se poderá pagar no próximo ano. Este colapso de expectativas é o colapso da própria Sociedade, o colapso do contrato social, e o contrato das populações descartáveis, são processos de exclusão irreversíveis, como indica Santos.

Ao distinguir claramente a esfera pública e a esfera privada, os pais da Democracia Liberal tentaram reconciliar a lógica unidimensional dos interesses com a tradição humanista que de toda pessoa se tem um sujeito: o cidadão dos tempos modernos era um ser duplo, mas preservava certa unidade interior em cada uma das facetas de sua vida. Com o abandono dessa dicotomia, a separação entre público e privado começa a desaparecer, banaliza-se, e esta banalização pulveriza a ideia de cidadão, que é o outro fundamento da Democracia Liberal, como defende Guéhenno. ${ }^{14}$

O que é a liberdade num mundo sem regras? Como se limita o poder num mundo sem princípios? Desde o Século XVIII, vincula-se a idéia de Democracia com a de Liberdade. Mas a liberdade tem dois sentidos muito diferentes: para uma coletividade humana, tem sido o Direito de definir seu próprio destino e, portanto, de dotar-se de um governo que expresse a vontade coletiva. Mas também é o Direito, de cada homem, de proteger-se dos abusos de poder cometidos pelo Poder Público, a garantia de que a maioria não esmagará a minoria.

Até mesmo Kelsen, um dos maiores teóricos da democracia formal, advertiu que o poder é a capacidade de influenciar os outros. Uma pessoa tem poder sobre as demais se puder induzi-las a se comportar conforme a sua vontade. O poder, portanto, não é político nem econômico, porém é político e econômico o meio utilizado para se alcançar tal comportamento.

Com a pós-modernidade, é evidente que está morrendo a primeira concepção da liberdade e que o melhor que se conseguiu obter foi, muito provavelmente, a limitação do Poder Público. Há um progressivo e evidente fenecimento do conceito moderno de liberdade, pois, de fato, só o homem rico a possui. 


\section{DEMOCRACIA E GLOBALIZAÇÃO}

A partir do paradigma do liberalismo globalizado dominante, consolidado com o fim da União Soviética, em 1989, a Democracia passou a ser concebida como um instrumento de otimização do mercado capitalista ${ }^{15}$. Mas esta maneira de ver a Democracia exclui toda forma de identidade política que não seja a dos cidadãos ou grupos como meros agentes portadores de interesses egoístas e em inevitável conflito entre si. Enfoque totalmente insuficiente, caso se queira fazer frente aos novos desafios e assumir o pluralismo cultural que cada vez se reclama mais no mundo global.

Corremos o risco de viver em sociedades que são politicamente democráticas, mas socialmente fascistas, tal como a Sociedade burguesa do início do Estado Constitucional Moderno. ${ }^{16}$ Nada mais natural, portanto, que a forma excludente e mono-classista retorne à sua essência.

Os ataques ao potencial democrático de monitoramento em meio a crises vêm de todos os lados. A soberania dos parlamentos e governos nacionais se reduz e, em escala mundial, faltam meios políticos democráticos para estabilizar o frágil sistema de uma economia de livre mercado. O capitalismo assim avançado acaba sendo um predador absolutamente destrutivo ${ }^{17}$. A fome e a miséria aumentam e a extensão do consumo de recursos e da destruição do ambiente, em continuação quantitativamente ampliada, pode determinar um colapso em escala global $^{18}$ que requer de um novo institucionalismo. A globalização se está convertendo na essência de um novo Direito Econômico Internacional que suprime a participação democrática em benefício de um descarado decisionismo tecnocrático, como indica Del Cabo ${ }^{19}$, uma vez que sepulta os mais elementares princípios de publicidade sob o império da opacidade e do segredo. Neste contexto, amplos contingentes sociais são atingidos em seus direitos mais básicos, por normas que os ignoram completamente. Aprovadas por uma elite que muito poucas vezes opera na superfície e quase sempre nos subsolos do complexo jogo político ditam normas que tornam absurdos certos pressupostos que o "poder" presume estejam disponíveis para conhecimento público, como o que sustenta que "o Direito se presume conhecido por todos" ou, pior ainda, aquele conforme o qual a Democracia supõe a atribuição a cada pessoa um voto.

A sensação de vazio, mais ou menos estendida entre os cidadãos das democracias modernas tem diversas origens e, é possível dizer, diversas caras: a desorientação dos indivíduos na estreiteza da vida privada, a ausência de conteúdo espiritual do mundo do dinheiro, o hedonismo desenfreado, o relativismo intelectual. Em suas relações com a evolução da vida política, esta sensação de "vazio" expressa o final de um ciclo histórico bicentenário, compreendido entre a Revolução Francesa - que representa as revoluções burguesas do Século XVIII - e a queda do Muro de Berlin. Tudo que ela representou e que foi vivida recentemente, provavelmente está sendo enterrada em suas diversas dimensões.

É certo que a Revolução Francesa e a Revolução Russa, vistas de uma maneira muito abstrata, tiveram em comum a idéia de construir uma Sociedade nova baseada na vontade e na razão. Mas a relação entre a Filosofia das Luzes e a idéia revolucionária é complexa. Além disso, a tradição ilustrada não esteve 
contemplada integralmente na utopia revolucionária, já que não representa mais do que uma de suas modalidades. O que surpreende neste começo de Século é o fato de que o projeto revolucionário - de transformar bruscamente a Sociedade apoderando-se do Estado - esteja quase morto na cultura política ocidental. De fato, o que hoje se assiste é a utilização da democracia, entendida como procedimento, precisamente para acabar com a democracia como modo de vida social através dos mais diversos governos de legitimidade discutível e que subordinam os valores cívicos universais aos seus interesses.

Neste ponto não se pode olvidar que o sucesso do sistema democrático da antiguidade encontrava-se precisamente no fato de que esta estrutura não era apenas um modelo formal de organização social. Enquanto indivíduo, o homem já se entendia como cidadão, era uma concepção indissociável, essa é, inclusive, a origem do zoon politikon a que se refere Aristóteles. ${ }^{20}$ Tem-se assim que a inserção do homem na Sociedade era feita de modo que este fosse preparado a exercer suas atividades na cidade e pela cidade enquanto cidadão ${ }^{21}$, ao mesmo tempo em que possuía o dever de se encarregar da administração de seus próprios bens na esfera privada. $O$ que se conclui pelo exemplo que nos deixou a história é que não há modelo democrático que possa prosperar, se a Sociedade a que ele pertence não esteja em sintonia com o mesmo. ${ }^{22}$

No contexto atual, não se deve perder de vista que o processo de globalização em curso não só tem caráter econômico, mas muito fundamentalmente caráter político, ainda que formalmente não se apresente assim. ${ }^{23}$ Por trás de um viés economicista se esconde uma orientação política muito concreta, ou melhor dizendo, uma forma de dominação, que, disfarçada de apolítica, expulsa os cidadãos para um mundo de redes anônimas que escapam de todo controle e a toda lógica democrática. Este mundo das redes está dominado pelas grandes empresas transnacionais, administradoras de uma economia global que tende ao oligopólio na maioria dos setores. Estas empresas estão, além disso, abertamente aliadas ao poder estatal na sua tarefa de socialização do risco e do custo, assim como na repressão àquilo que não seja "politicamente correto".

As sociedades tidas como democráticas se confrontam, atualmente, com uma série de novos desafios para os quais não estão preparadas, devido à perspectiva racionalista que informa as principais correntes da teoria política. ${ }^{24}$ Caso se queira estar apto a uma nova compreensão da Democracia, a qual possa fornecer uma resposta ao novo conjunto de demandas ligadas à pós-modernidade, é preciso superar a construção teórica da modernidade, apesar de se saber que a que virá conviverá com esta.

O Direito que adviria de um ambiente político-jurídico transnacional seria forjado, muito provavelmente, com base em princípios de inclusão social e proteção ao ambiente. A sustentabilidade e a solidariedade passariam a ser os principais itens da pauta do milênio. Neste novo modelo de organização social que está por surgir, é essencial que os princípios de uma formação humanista que servira de base para a construção da civilização ocidental sejam atualizados ao modo como a humanidade se encontra na realidade contemporânea, não se perdendo por esta via a busca por realização do valor humano nesta reorganização política. 
Um dos paradigmas a serem rompidos para tanto será a crença na Democracia Representativa como suficiente para capilarizar, transferir e transformar em normas jurídicas as demandas oriundas do processo de desterritorialização do Estado Constitucional Moderno. Ela está em crise. Muito provavelmente em sua crise transformadora, principalmente nos espaços políticos globais.

\section{A DEMOCRACIA OBSOLETA}

Durante mais de meio século cultivou-se a existência de duas democracias: a formal e a real, a capitalista e a socialista comunista. Esta "alternativa inexistente" teve que se desmanchar entre as mãos para que fosse reconhecida a sua inexistência. Mas, neste momento, a falácia está bem visível, e todos podem vê-la. A Democracia venceu, e a Democracia que venceu é a única "real" que se realizou nos últimos dois séculos: a Democracia Liberal. E isso é um problema.

Como diz Sartori ${ }^{25}$, perder o inimigo muda todos os pontos de referência. Paradoxalmente, ainda que não tanto, perder o inimigo externo destapa a caixa de Pandora dos problemas internos. Por um lado, é impossível não reconhecer a hegemonia da Democracia Liberal. Por outro lado, e ao mesmo tempo, pode ser cada vez mais difícil administrá-la. Por enquanto é preciso reconhecer que os paradigmas estão mudando ou mudaram, mas sem esquecer que a tarefa mais imediata é compreender o fenômeno da globalização e seus efeitos sobre a Democracia, sempre com certa imunidade a triunfalismos exagerados e prematuros.

Está-se vivendo um momento no qual o mundo não pode mais ser representado de acordo com as categorias do passado, e no qual pode-se reconhecer na realidade atual fenômenos de desintegração social, de fragmentação cultural, de niilismo ${ }^{26}$ intelectual, de alienação individual, com os processo de anomia social adquirindo contornos dramáticos. Entretanto, essa mesma desintegração social e desconcerto intelectual são componentes a mais de um processo de mudança no qual poderão ser encontrados os novos paradigmas a serem estabelecidos.

Heller, em 1928, já chamava a atenção para o perigo do desequilíbrio sócioeconômico para a Democracia. O autor alemão vaticinava que não seria possível o funcionamento do sistema representativo com as regras capitalistas liberais. Ele ponderava que a democracia política derivada da disparidade econômica entre as classes poderia ser mitigada, num primeiro momento, em países com maior homogeneidade, mas o conflito voltaria, inexoravelmente, em lugares nos quais a realidade não fosse essa.

Quanto mais numerosos forem os grupos e os círculos sociais que adotam sua segregação como castas, com requisitos aos que queiram ser nela admitidos, quanto mais efetiva é a estrutura convencional conforme a posição social em educação e ensino, quanto mais intensa for a exigência para ocuparem cargos públicos, tanto maior será a consciência da desigualdade de classes e da desigualdade política. Heller, anota que a homogeneidade antropológica é uma 
condição prévia à Democracia Representativa. Ele aponta que, sem um certo grau de homogeneidade social, a própria homogeneidade cultural resulta impossível. Diz ainda que as esperanças das elites de que a participação do proletariado na cultura nacional será suficiente para manter dentro de parâmetros aceitáveis a formação democrática homogênea das classes despossuídas é, em grande parte, uma percepção ingênua. Segundo ele, a autêntica participação na Nação só pode ser alcançada quando todos se sentem espiritualmente participantes. Todo o resto se desfaz na mera comunidade de interesses, ou fica absorvido por ela. Heller já antevia o crescimento do nazi-fascismo, alavancados pelos desequilíbrios capitalistas liberais. ${ }^{27}$

A Democracia Pluralista moderna sempre supôs, portanto, que as lutas de classes não superassem um determinado grau, com a desigualdade e a opressão material conservadas em dimensões razoáveis, ou que a consciência dessa opressão fosse débil, com os oprimidos sem meios para combatê-la. Por outra parte, as diferenças de raças, nacionalidades ou religiões que até hoje eram consideradas menos importantes ou gerais, tenderão progressivamente a se converter em decisivas. Elas tendem a diluir a sensação de fazer parte, que é a conjunção espiritual imprescindível para construir uma Sociedade razoavelmente homogênea e democrática e - o que é pior - não são compartilhados os princípios éticos e morais básicos que permitem ordenar as relações sociais, sobretudo no caso dos coletivos religiosos de corte integrista que rechaçam algumas regras fundamentais de convivência por entrar em colisão com seus fundamentos morais. Duverger $^{28}$ indica que essa opressão material típica da modernidade, acabou por tornar-se a sua marca registrada.

Pode-se anotar, portanto, que eleições e novas constituições não são suficientes sem o desenvolvimento de uma nova cultura democrática que não seja só procedimento, como escreve Miglino. ${ }^{29}$ A cultura democrática atual está afetada pela pobreza do debate público. A discussão sobre os princípios dos sistemas políticos, das visões gerais da Sociedade e de soluções para poder lidar com problemas sociais é, normalmente, substituída por imagens pictóricas dos candidatos, com posições extremamente vagas e apelos aos motivos mais emotivos. Existe uma marcada falta de seriedade em todo o processo e isto faz com que os candidatos eleitos não se sintam obrigados a seguir o resultado do debate público, como analisa Nino. ${ }^{30}$

Rousseau ${ }^{31}$, colocando restrições à Democracia Representativa, ao escrever que a soberania não pode ser representada, pela mesma razão de que não pode ser alienada. O pensador escreveu que a Democracia Representativa consiste, essencialmente, na vontade geral, e a vontade geral não se representa para nada. É ela mesma ou é outra. Não tem meio termo. Os deputados do povo não são nem podem ser seus representantes, pois são apenas seus comissários. Nada podem concluir definitivamente. Toda lei que o povo, pessoalmente, não tenha ratificado, é nula. Não é uma lei.

Os sistemas adotados pelas democracias ocidentais não são menos oligárquicos ou plebiscitários - ou referendários, como quis De Gaulle na França que o de partido único. ${ }^{32}$ As democracias, como todos os regimes de governo, são conversíveis em oligarquias, já que sujeitas às "partitocracias", formadas a partir de 
uma elite dirigente. Assim, a soberania popular não passa de uma falácia, exercida optando-se entre oligarquias partidárias e burocráticas.

Quanto mais amplo for o dispositivo público da economia, maior será a incidência deste dispositivo sobre a totalidade do sistema produtivo, tanto mais ampla é a brecha aberta na cobertura exterior do capitalismo, tanto mais profunda é a contradição que a Democracia representativa introduz no interior da Sociedade capitalista.

Por isso, não pode ser considerado realmente democrático, um sistema político que não permite nenhuma forma incisiva de controle sobre aqueles que comandam através das ferramentas da economia. Como foi salientado, dado que o poder político pode controlar o poder econômico, a democracia política é também o único meio de controle do poder econômico, da parte dos governantes. Mas hoje, como demonstram as recentes crises financeiras, os Estados nacionais não são capazes de conter a absoluta liberdade das aristocracias econômicas. A situação de subordinação de grande parte da população em relação a quem domina a produção, o comércio e a economia, se concilia com a prevalente noção de democracia representativa, segundo a qual os processos eleitorais são suficientes para realizar o "poder do povo". É claro então, que o significado processual da democracia representativa não impede a prevaricação do homem sobre o homem. Para construir um conceito de democracia que possa ser empregado em nível estatal e transnacional a fim de construir paz e justiça, não se deve subestimar a sugestão de quem acredita que é necessário olhar o poder político com ceticismo liberal, e o poder econômico com ceticismo marxista. Uma realização completa dos princípios de liberdade, igualdade e solidariedade, leva a aceitar uma noção complexa de democracia na qual o elemento principal não é o processo, mas a difusão de todo tipo de poder, seja este político, econômico, da mídia, cultural, social. Somente evitando a concentração das prerrogativas que permitem comandar a nível nacional e transnacional, e promovendo a sua difusão, se consentirá a cada pessoa de participar na realização de um projeto de vida autônomo. Para passar da democracia representativa à democracia participativa é necessário difundir o poder em qualquer modo que este se manifeste na realidade. A tal finalidade, devem-se imaginar mecanismos e instituições novas para unir as realidades locais àquelas globais.

Ele acabou se desviando para acabar legitimado em diferentes regimes autoritários e seus herdeiros atuais, defensores da participação, ainda enfrentam o dilema original: o exercício do controle popular coletivo sobre os centros de poder existentes é compatível com o intento simultâneo de dispersão do poder?

Montesquieu nos ensinou que para limitar um poder é preciso intervir o poder jurídico. Então, para impedir que a concentração de prerrogativas no campo financeiro atribua uma absoluta liberdade a uma classe gerencial desprovida de limites, se poderia imaginar uma instituição que opere em nível transnacional, com poderes diretamente vinculantes no que diz respeito às empresas e aos países. ${ }^{33}$

Isso se concilia com uma concepção de democracia entendida como desconcentração do poder, justamente porque esta concepção não diz respeito somente ao poder político, mas a todas as formas de gestão de recursos que 
consentem comandar. O sistema financeiro, no seu complexo, se tornaria mais republicano se fossem aplicadas regras oportunas aos administradores que agem em nível mundial. Para limitar um poder financeiro que já está concentrado em nível transnacional, só nos resta instituir um novo Direito que também opere em âmbito transnacional. As possíveis soluções para resolver os problemas relacionados ao poder do homem sobre o homem são sempre ligadas à abordagem epistemológica que se espera ter na definição do conceito de democracia. ${ }^{34}$ Uma visão que valoriza a democracia como participação e difusão do poder no âmbito transnacional comportaria, certamente, a superação das tradicionais categorias jurídicas e políticas do Direito Internacional clássico. É tempo de superar realidades cujas origens remontam ao século XVII: o tratado da Westfália já vai longe.

A Democracia de hoje deve atender a um equilíbrio de poderes entre os legitimados pelos votos, os legitimados por suas iniciativas de base e os legitimados por seus conhecimentos técnico-profissionais. Nenhum deles, sozinho, pode pretender ter a verdade da vontade democrática ${ }^{35}$. E mais: provavelmente 0 peso destas fontes de legitimação deva ser diferente segundo o cenário no qual devamos assegurar o respeito aos princípios democráticos. Os partidos políticos, se não oportunizarem a participação dos três segmentos, acabarão numa situação de afastamento das suas bases. $E$ os outros movimentos, caso não adotem igual postura, podem acabar enredados por um populismo sem controle, assim como os grandes movimentos corporativos profissionais, sem a necessária abertura, podem acabar em tecnocracia, que também nega a essência democrática. Hoje existem experiências, ainda incipientes, de como articular essas três legitimidades. Trata-se de desenvolver esta lógica para aportar mais experiências criativas e dinamizadoras ${ }^{36}$, como escreveu Villasante.

Para dar respostas às velhas e novas questões, é oportuno ter em conta que o fato de que as inovações tecnológicas se manifestam numa fase histórica na qual as formas tradicionais da Democracia Representativa aparecem sempre mais claramente afetadas por um distanciamento crescente dos cidadãos, manifestado, principalmente, através da escassa participação eleitoral. Volta assim à necessidade de uma participação não intermediada, de uma intervenção direta dos cidadãos, que pode ser obtida através das novas tecnologias. ${ }^{37}$

Provavelmente, para superar os limites da Democracia Representativa, será necessário encontrar uma complementaridade com a Democracia Participativa. É assim que escreve Santos $^{38}$, ao predizer que a Democracia Participativa será um campo para se criar "alternativas de Sociedade".

A Democracia somente pode subsistir, isto é, continuar viva, com processos permanentes de ampliação de democratização. ${ }^{39}$ Como não é o caso hoje em dia. Há, isto sim, uma diminuição do processo de democratização.

Como a Democracia Representativa tornou-se vulnerável demais aos interesses do mercado econômico e político, cada vez mais juntos e promíscuos, a Democracia Participativa pode trazer outros valores de cooperação e de solidariedade. Como o momento histórico é favorável, também se faz importante a formação do homem para este modelo de Democracia Participativa, preparando-os de modo que, estabelecido este novo sistema de organização, as pessoas estejam 
materialmente aptas a se valer dos instrumentos a ela disponibilizados e também possuam o conhecimento necessário para conduzir a Sociedade em direção ao que é melhor ao corpo social. Foi pela formação de seus cidadãos que os modelos grego e romano puderam perdurar por um longo período na história ${ }^{40}$, e o declínio de ambos coincide com a decadência do ideal de Sociedade de cada uma dessas civilizações. $^{41}$

O acesso à participação democrática, num cenário mundial de civilizações em conflito e multicentrado remete a discussão a pontos muito distantes do modelo do Estado Constitucional Moderno. São questões profundas, inquietantes, sobre o modelo da maioria e de todo o sistema de voto para expressar preferências.

Em função dessa premissa é que estão em crise, definitivamente, os anacrônicos métodos do Estado Constitucional Moderno. A Democracia de Minorias - ou sem minorias ou maiorias - deve revelar diferenças muito mais que formar bases de maiorias falsas ou forçadas, hipócritas, mercenárias, fraudulentas. Outro modelo deve transformar tendências em maiorias e relativizar os termos do Estado Constitucional Moderno. As elites governamentais sempre se lambuzaram com a Democracia Representativa na tentativa de determinar a vontade da Sociedade. A simplificação do "sim" ou "não".

Mas já se sabe que não há Democracia sem participação, como afirma Bonavides. De sorte que a participação aponta para as forças sociais que vitalizam a Democracia e Ihe ensinam o grau de eficácia e legitimidade no quadro social das relações de poder, bem como a extensão e abrangência desse fenômeno político numa Sociedade repartida em classes ou em distintas esferas e categorias de interesses ${ }^{42}$. A renovação da teoria democrática assenta, antes de tudo, na formulação de critérios democráticos de participação que não confinem esta ao ato de votar. Implica, pois, uma articulação entre democracia representativa e democracia participativa. Para que tal articulação seja possível é, contudo, necessário que o campo do político seja radicalmente redefinido e ampliado.

A teoria política liberal transformou o político numa dimensão setorial e especializada da prática social - o espaço da cidadania - e confinou ao Estado Constitucional Moderno. ${ }^{43}$ Do mesmo modo como todas as outras dimensões da prática social foram despolitizadas e, com isso, mantidas imunes ao exercício da cidadania. O autoritarismo e mesmo o despotismo das relações sociais "não políticas" (econômicas, sociais, familiares, profissionais, culturais, religiosas) pôde assim conviver sem contradição com a democratização das relações sociais "políticas" e sem qualquer perda de legitimação para estas últimas.

Santos defende que a nova teoria democrática deverá proceder a repolitização global da prática social e o campo político imenso que daí permitirá encontrar formas novas de opressão e de dominação, ao mesmo tempo em que criará novas oportunidades para o exercício de novas formas de democracia e de cidadania.

Por tudo isso, a construção de um espaço sócio-político multicultural passa por lograr que as pessoas conquistem poderes democráticos onde vivam e trabalhem, na cidade, na escola, na empresa, no escritório, para que possam 
decidir sobre suas necessidades e estabeleçam outros tipos de vínculos sociais. Para isso, será necessário que, antes, se defina os novos espaços públicos e privados, nos quais se assentarão os novos poderes públicos que venham a existir depois do Estado Constitucional Moderno.

\section{A POSSIBILIDADE DA DEMOCRACIA TRANSNACIONAL}

Um dos principais problemas enfrentados pelas democracias contemporâneas é a perda da capacidade de autodeterminação, derivada do fato de que muito do que afeta o bem estar de suas populações se encontra agora fora do controle nacional. Sem dúvidas, o problema acarreta outras questões: a degradação do meio ambiente, o controle dos recursos naturais, os movimentos migratórios e as mais tradicionais ameaças militares. ${ }^{44} \mathrm{Na}$ atualidade, nenhuma democracia pode isolar-se dos efeitos do que acontece além de suas fronteiras.

Em cada momento, incluindo o atual, o desenvolvimento da Democracia se apresenta de modo desigual e incompleto. A Democracia não conseguiu alcançar outras formas de vida fora da política e nem outras ordens políticas que não aquelas restritas ao Estado Constitucional Moderno ${ }^{45}$. Em qualquer caso, não é muito congruente a ideia de Democracia como valor conformar-se com sua aplicação limitada ao Estado Constitucional Moderno e não à nova ordem externa; e à política, e não à ordem política em geral.

A análise da política democrática conduz, necessariamente, no plano dos conceitos, à insuficiência do Estado Constitucional Moderno perante a nova realidade mundial, que por dever ser democrática, deve ser um ordenamento voltado à paz e à justiça ${ }^{46}$. Não se trata de uma utopia, no sentido mais usual do termo, mas sim de uma conclusão lógica a partir da premissa maior da validade de um Poder Público democrático.

Inserir um país nos espaços centrais da Sociedade global, ou incorporá-lo ao núcleo de sua estrutura multiforme e mutante é hoje fundamental. O Poder Público, por mais forte, eficaz e bem dirigido que seja, sozinho não é capaz de controlar a marcha desaforada da economia, a pesquisa de ponta ou os meios de informação ${ }^{47}$. É preciso as alianças ou coincidências com outros poderes, e com sua gente, que é o que lhe dá força e legitimidade. Para situar um Poder Público verdadeiramente democrático numa dinâmica de futuro, de forma inexorável é preciso contar com a rapidez de adaptação das sociedades às mudanças tecnológicas e organizativas, ao acesso às informações em tempo real e aos novos produtos, à participação nos novos espaços de criação de riqueza e bem estar.

Tudo muda quando a atividade humana se libera do espaço, quando a mobilidade do homem e da economia faz voar em pedaços as demarcações geográficas. Substituída por agrupamentos temporários de interesses, desaparece a solidariedade espacial das comunidades territoriais ${ }^{48}$. O Estado Constitucional Moderno e sua pretensão de combinar em um único marco as dimensões política, cultural, econômica e militar do poder é prisioneiro de uma concepção espacial do poder, mesmo quando tenta redistribuir suas competências segundo um princípio federal. O espaço deixou de ser um critério pertinente ou preponderante. 
A Democracia exige que processos econômicos sejam inseridos em processos sociais - na situação atual, necessariamente, com a ajuda de um conjunto de espaços públicos de governança transnacionais - à medida que o Estado Constitucional Moderno não pode mais por si só fornecer, a título de dados de orientação, o quadro vinculante. Do contrário, os processos de mercado, livres do Estado, fazem com que a soberania dos Estados Constitucionais Modernos e a sua legitimidade democrática degenerem paulatinamente em farsa, como indica Müller ${ }^{49}$.

A humanização e civilização da globalização, no âmbito da Sociedade Civil têm, portanto, uma função distinta: não se trata de enfraquecer o veneno, mas de responder com um contraveneno; não se trata de implodir a globalização, mas de fortalecer a Democracia por meio da mobilização dos democratas de forma radical. ${ }^{50}$ A Democracia radical, como expõe Mouffe ${ }^{51}$, exige que se reconheça a diferença - o particular, o múltiplo, o heterogêneo -, tudo o que, na realidade, tenha sido excluído pelo conceito abstrato de homem. O universalismo não seria rejeitado, mas particularizado. Um novo tipo de articulação entre o universal - ou global - e o particular ou local. Beck chama de "glocal", já que para ele o marco de referência teria mudado. A proposta seria "pensar globalmente e agir localmente"

Tratar-se-ia de postular um progressivo transnacionalismo ${ }^{53}$ jurídico erigido não sobre a negação da diferença regional ou nacional das populações, mas, pelo contrário, sobre uma profunda - e radical - articulação democrática de sua pluralidade e de suas múltiplas identidades culturais.

O "estatalismo", no sentido da admissão do Estado Constitucional Moderno como sendo ainda uma construção político-jurídica suficiente para o mundo pósqueda do Muro de Berlim, é, sobretudo, contraditório com o pleno desenvolvimento da Democracia ${ }^{54}$. Há democracias ameaçadas "de fora" pelo terrorismo, a corrupção e o narcotráfico. Sem dúvidas, uma Democracia já é cativa de si mesma quando se conforma com os limites estatais que impedem sua maturação e desenvolvimento.

A linha de raciocínio presente neste artigo indica a superação do Estado Constitucional Moderno pelo necessário avanço de um ordenamento democrático transnacional e que tenha como finalidade realizar a paz, como anota Bilbeny ${ }^{55}$. Não se trata de uma utopia, no sentido mais usual do termo, mas de uma conclusão lógica a partir da premissa maior de validade de uma política democrática.

Sendo a Democracia um regime de paz por acordo, e não por vitória, como num regime autocrático, a superação de um ordenamento estatal calcado na Soberania moderna tem que ser na direção de um ambiente mundial democrático que possa garantir melhor a paz que um ordenamento regional de território determinado. Há um evidente retrocesso da Soberania ${ }^{56}$ Moderna nos estados de um modo geral, com uma interdependência cada vez maior, especialmente na ordem econômica e no que diz respeito à preservação do meio ambiente.

Definitivamente, um ordenamento transnacional de paz - uma verdadeira política mundial - é um conceito extraído do próprio conceito de Democracia. 
Mesmo que esta idéia, no aspecto prático, possa parecer prematura, não quer dizer que seja uma utopia no seu sentido emblemático. Também não se trata de expressar qualquer tipo de voluntarismo cosmopolita. A oposição entre uma ordem mundial e outra estatal não é uma antítese absurda (e contraproducente) entre o transnacional e o nacional, o universal e o particular, o desaparecimento do poder e sua viçosa sobrevivência ${ }^{57}$. O que está em jogo na possibilidade de uma ordem mundial diante de uma ordem estatal é a primazia da Democracia contra a autocracia, o que é o mesmo que se confrontar a paz e a guerra. Só em uma verdadeira política mundial a guerra deixa de legitimar-se como discurso político e fica restrita ao debate entre defensores do diálogo e os partidários da violência tribal.

É provável que a democratização das instituições transnacionais seja lenta e passe pelo aumento do alcance dos instrumentos já existentes, como os convênios e tribunais de direitos humanos, ou os parlamentos regionais, como o parlamento europeu. Sem dúvidas, a urgente necessidade de encontrar soluções transnacionais para os problemas mundiais faz com que o objetivo de um poder político de representação mundial, com poderes efetivos de coerção, e a existência de uma correspondente cidadania mundial, não seja nem utópico nem extravagante.

A transnacionalização da Democracia exigirá uma limitação efetiva da Soberania dos estados, mas, ao contrário do que ocorre com freqüência no momento atual, essa limitação não deve e nem pode ser exercida por outros estados $^{58}$. A mundialização e a progressiva interdependência das relações está configurando, de fato, a formação de um novo âmbito de interesse geral, que se situa em fronteiras transnacionais e que, agora, começam a se concretizar de maneira muito intensa na defesa dos direitos humanos. Só será viável a universalidade dos direitos humanos a partir da superação dos limites estatais modernos da Democracia, como afirma Jáuregui ${ }^{59}$.

É urgente, portanto, a discussão sobre a possibilidade de um Direito cosmopolita e de uma Democracia capaz de regular, limitar e configurar, para além da fronteiras do Estado Constitucional Moderno, uma verdadeira nova ordem, uma verdadeira ordem global democrática de Direito, capaz de superar a atual ordem, debilitada e caduca. Uma nova ordem que seja capaz de reduzir as três "brechas" que dificultam a construção social transnacional: a brecha jurisdicional, que não é mais que a discrepância entre um mundo globalizado e as unidades nacionais relativas à formulação de normas; a brecha da participação de novos atores e cidadãos nos espaços de governança transnacional, ou seja, na extensão transnacional da democracia; e a brecha dos incentivos, entendidos como mecanismos de ajuda aos países em desenvolvimento para fazer efetiva a cooperação internacional. ${ }^{60}$

\section{A DEMOCRACIA PARA DEPOIS DA MODERNIDADE}

A Democracia é um voto de confiança no homo sapiens, num animal inteligente a ponto de criar e gerir uma "cidade boa". Mas se o homo sapiens está em perigo, a Democracia também está. As ideologias da modernidade não 
lograram criar um "homem novo", mas, com certeza o Poder Transnacional ${ }^{61}$ o está criando. Até agora, o poder de formar o homem (antropogenético) do "ciberpoder" não conseguiu chegar a bom termo, porque as gerações formadas por "coisas lidas" se opuseram. Mas dentro de pouco tempo tudo passará ao homem (realmente unidimensional) formado pelas "coisas vistas". Algo diferente do que propunha Marcuse. E diferente do fim da história. A história está voltando a começar sobre premissas que superam, inclusive, nossa capacidade de imaginação.

Com maior razão, não se pode proceder, portanto, "como antes", usando as palavras de Sartori. ${ }^{62}$ As políticas herdadas são, em boa parte, políticas ruins que indicam que devemos pensar no novo. A boa notícia - entre todas que não são - é que o fim das ideologias modernas permite verdadeiramente "repensar", ou seja, voltar a pensar livremente, repensar sem medo. Isto é magnífico, como diz o autor italiano.

Há uma enorme necessidade de se pensar de novo. O novo. Hoje, quem se atreve a governar sem Democracia, atua sem legitimidade. Mais cedo ou mais tarde será sacado do poder. Mas, inclusive o jogo democrático pode ser mal jogado. Saberá a Democracia resistir à Democracia? É muito provável que sim, desde que se jogue com muito mais inteligência, sentimento humano e, sobretudo, responsabilidade do que se joga hoje. É possível a Democracia ser o paradigma desse novo tempo que começa, porque o pessimismo da inteligência pode ser combatido com o otimismo da vontade.

Mas se não se estanca o fluxo irresponsável da proposta de um futuro "seguro", então é evidente que a Democracia perderá. A euforia é sempre breve. A euforia da queda do comunismo, e da globalização, já estão passando e os perigos são iminentes. É preciso ter cuidado com os discursos inúteis, com as pretensões descabidas.

Um mundo novo está tomando forma neste início de milênio. Um novo mundo que surgiu da coincidência histórica de três processos independentes: a revolução da tecnologia da informação; a crise econômica tanto do Capitalismo como do Socialismo de Estado; e o florescimento de novos movimentos sociais e culturais. ${ }^{63}$ A interação destes processos e as reações por eles desencadeadas criaram uma nova estrutura social dominante, a Sociedade rede; uma nova economia, a economia informacional/global; e uma nova cultura, a cultura da virtualidade real, como demonstra Jáuregui, citando Manuel Castells. ${ }^{64}$

Este novo mundo, ainda emergente, está provocando uma profunda ruptura e uma enorme descontinuidade com relação à modernidade e, por isso, é adequada a qualificação de "novo" no mais estrito sentido da palavra. Aqueles que querem expandir a liberdade humana hoje baseada em conceito formal ligado à riqueza, não serão capazes de fazer isso apenas defendendo nossas instituições já existentes. Será preciso propor novas instituições. O Estado que as elites modernas moldaram, inclusive os próprios princípios em que se basearam, está cada vez mais obsoleto, cada vez mais opressivo e perigoso para o bem estar geral. Está cada vez mais visível a necessidade de ser teorizada uma nova 
arquitetura político-jurídica para o Estado e uma democracia para a pósmodernidade. ${ }^{65}$

Santos expressa sua tese acreditando que existam, atualmente, condições objetivas que tornem possível a criação de uma Democracia de alta intensidade, combinando, articulando em uma complementaridade criativa, a Democracia Representativa e a Democracia Participativa ${ }^{66}$. Então, qual a diferença entre democracia representativa e democracia participativa? $\mathrm{Na}$ democracia representativa os cidadãos elegem quem vai politicamente decidir. Na Democracia Participativa os cidadãos tomam as decisões políticas.

O modelo de representantes para decidir pelos outros cidadãos funcionou bem com as representações burguesas homogêneas, quando o conjunto de cidadãos a serem representados era monolítico e o consenso era facilmente alcançado. Com a multilateralidade da Sociedade Contemporânea, evidente que a Democracia Representativa começaria a apresentar sérios problemas.

Como já foi dito, não adianta reformar o Estado Constitucional Moderno e a Democracia Representativa Parlamentar. É como querer que a hélice de um avião dos primórdios do Século XX sirva de propulsor para uma nave espacial. Há uma incompatibilidade crônica evidente.

Além do mais, se até agora a humanidade evoluiu e progrediu - pelo menos em alguns aspectos - desde a ausência de Democracia e do voto censitário, até o voto universal - que só foi alcançado muito recentemente em vários países, como a Suíça, onde as mulheres alcançaram o Direito de voto só em 1972 - por que não se pode pensar que a Democracia vai continuar progredindo e evoluindo no futuro ? $^{67}$ Por que não se poderá aperfeiçoar e melhorar os mecanismos de participação democrática? Quem decidiu que nos encontramos num "ponto morto" quanto ao avanço da Democracia ou, inclusive, diante da possibilidade de certos retrocessos?

Por tudo isso é preciso contemplar as perspectivas da dinâmica política com "otimismo histórico" e compreender que, no longo prazo, há uma tendência clara de progresso, ainda com fases e períodos de retrocesso, e que, portanto, a idéia de Democracia continuará evoluindo e desenvolvendo-se. O mesmo não se pode dizer do Estado Constitucional Moderno.

\section{CONCLUSÃO}

Como foi possível perceber, ao longo do artigo, por detrás das teorias que procuram orientar a adoção de "democracias" capazes de coexistir com a diversidade e com a complexidade, com a solidariedade e a participação, existe embutido um otimismo irrefutável quanto à possibilidade da elaboração do que poderia ser chamado de uma teoria democrática transnacional ${ }^{68}$. Atrás deste otimismo está a idéia de que a pós-modernidade é característica de uma crise no projeto epistemológico da modernidade e não de seu projeto político. 
Sendo válido pensar numa ordem pós-capitalista liberal, também é válido refletir sobre uma ordem pós-estatal moderna: as incertezas e justificativas morais coincidem, tanto empiricamente - sendo o Estado Constitucional Moderno agente do capitalismo - quanto filosoficamente - sendo o próprio Estado o signo da hierarquização entre os homens. Se o que se quer é uma ordem livre e igualitária, é fundamental pensar na superação democrática do Estado Constitucional Moderno.

Hoje, como a recente crise financeira demonstrou os estados nacionais não são capazes de conter a absoluta liberdade da aristocracia econômica. A situação de subordinação de grande parte da população nos confrontos de que domina a produção, o comércio e as finanças se acorda a prevalente noção de democracia representativa, segundo a qual os procedimentos eleitorais bastam para realizar o "poder do povo". O que foi considerando foi exatamente a diversidade democrática. Povos e países de várias partes do mundo estão reinventando a Democracia, uma Democracia de alta intensidade, através de iniciativas populares. Nelas há uma energia democrática muito forte. A responsabilidade de cientistas e líderes dos movimentos sociais é ver toda essa energia.

Essa energia, na esteira do que escreve Eccleshall ${ }^{69}$, significa que o objetivo principal da Democracia não é o de resolver as diferenças através do voto, mas estimular e consolidar os hábitos mentais que assegurem a eliminação dos motivos de queixa e a harmonização dos pontos de vista antes de se começar a votação propriamente dita.

No caso, deixar-se-ia de entender o Estado Democrático de Direito como uma proposta de civilização e se passaria a ter a Democracia como proposta de civilização, muito mais pluralista e resistente às mudanças próprias do desaparecimento de uma era e o surgimento de outra.

As novas formas democráticas entram em cena para questionar a Democracia Representativa como suporte apenas procedimental do organismo denominado Estado Constitucional Moderno. A Democracia Representativa tem se mostrado extremamente vulnerável à força dos grandes poderes econômicos, resultado da contaminação entre o mercado econômico e o político, que tem reflexos nas privatizações dos serviços públicos, no financiamento público dos partidos e a invasão da mídia, que artificializa a política. ${ }^{70}$ Por outro lado, o que se percebe é que as "democracias" pós-modernas poderão promover o necessário processo de democratização da economia, dos meios de comunicação - inclusive a Internet e da utilização sustentável do meio ambiente, fundamentais para o futuro de humanidade globalizada ${ }^{71}$.

Assim sendo, se o futuro da humanidade se direciona a este sentido, é fundamental que a Sociedade também esteja se preparando para o novo modelo político que está por surgindo. ${ }^{72}$ Deste modo, neste novo contexto de superação do modelo representativo e, mais ainda, do próprio Estado Constitucional Moderno, tem-se como elementar a formação da humanidade para que esta esteja em sintonia com a nova dinâmica institucional que a transnacionalidade nos está trazendo. ${ }^{73}$ 
Deste modo, a nova teoria da Democracia - que também está designada como teoria democrática pós-moderna por significar a superação da teoria democrática liberal - tem, pois, por objetivo alargar e aprofundar o campo político em todos os espaços estruturais da intervenção social, como defende Santos ${ }^{74}$.

A diferenciação das lutas democráticas pressupõe a imaginação social de novos exercícios de Democracia e de novos critérios democráticos para avaliar as diferentes formas de participação política. E as transformações prolongam-se no conceito de cidadania, no sentido de eliminar os novos mecanismos de exclusão da cidadania, de combinar formas individuais com formas coletivas de cidadania e, finalmente, no sentido de ampliar esse conceito para além do princípio da reciprocidade e simetria entre direitos e deveres.

A idéia de reciprocidade constitui, portanto, um pressuposto moral da própria existência da comunidade, sendo que a integração da pessoa na comunidade ocorrerá somente quando ela puder tomar parte e ter interesse nas decisões coletivas e, em relação a elas, guardar sua independência individual. A concepção comunitária de Democracia, como escreve Dworkin, explica uma intuição partilhada por muitos: a de que uma Sociedade, na qual a maioria despreza as necessidades e pretensões de alguma minoria, é ilegítima e injusta.

As formas radicais da Democracia pós-liberal serão postas à prova neste Século XXI. Pelo menos nos países em desenvolvimento, como aponta também Tezanos $^{75}$. É possível afirmar-se que instituições serão criadas e que possibilidade de êxito terão. Pode-se sugerir o surgimento de uma Democracia pós-liberal aberta e não definida pela cidadania moderna internalizada.

O monopólio do Estado Constitucional Moderno como única fonte legítima de lealdade política para seus cidadãos começa a ceder seu lugar a um conjunto de identidades políticas mais pluralistas e múltiplas. As pessoas começam a se definir a si mesmas como membros de uma comunidade local, de uma nação ou uma federação multinacional, de uma região ou subcontinente, e como cidadãos do mundo. Esta evolução deve ser acolhida favoravelmente pelos democratas, já que os impulsos universalistas da Democracia e seus princípios orientam seus seguidores para além de qualquer compromisso com um só nível de proposição política e para além do Estado Constitucional Moderno, na direção de uma construção político-jurídica transnacional.

\section{POSSIBILITIES FOR DEMOCRATIC TRANSNATIONALITY}

\section{ABSTRACT}

This article addresses Representative Democracy and its inadequacy to deal with very complex societies. It considers the asymmetric nature of its representativity, and the urgent need for a reevaluation of the current models of Democracy that will enable them to adequately meet the current demands for participation. The hypotheses of this article are based on the premise that authentic 
participation in the Nation can only be achieved when all those involved feel they are participating in spirit.

Keywords: Asymmetric Democracy. Globalization. Modern Constitutional State. Participatory Democracy. Representative Democracy.

\section{NOTAS}

1 Professor da unidade de Direito da Universidade de Roma La Sapienza, Departamento de Direito Público, especialista em instituições de Direito Público, responsável pela disciplina de Direito Público. Advogado na Corte de Cassação. E-mail: arnaldo@studiolegalemiglino.191.it. Endereço: Viale dell'Università, 30, 00185 Roma, Itália.

2 Pós-Doutor em Direito do Estado pela Universidade de Alicante, na Espanha, Doutor em Direito do Estado pela Universidade Federal de Santa Catarina e Mestre em Instituições JurídicoPolíticas também pela Universidade Federal de Santa Catarina - UFSC. Coordenador e professor do Programa de Pós-Graduação Stricto Sensu em Ciência Jurídica da Universidade do Vale do Itajaí - UNIVALI em seus programas de Doutorado e Mestrado em Ciência Jurídica. Foi Secretário de Estado em Santa Catarina e Vice-reitor da UNIVALI. É professor visitante nas universidades de Alicante, na Espanha, e de Perugia, na Itália. E-mail: pcruz@univali.br. Endereço: Rua Uruguai, 458 - Centro, 88302-202 - Itajaí, SC - Brasil - Caixa Postal: 458. BOBBIO, Norberto, Il futuro della democrazia. Torino: Einaudi, 1995, p. 63.

BILBENY, Norbert. Política sin estado. Barcelona: Ariel, 1998, p. 172.

Sobre isso se recomenda: MIGLINO, Arnaldo. A cor da democracia. Florianópolis: Conceito, 2010. BILBENY, Norbert. Política sin estado. p. 174.

BECK, Ulrich. La sociedad del riesgo global: amor, violencia y guerra. 2. ed. Madrid: Siglo XXI, 2006, p. 76.

8 Sobre a evolução de alguns desses espaços, sugere-se ver PIPITONE, Ugo, Ciudades, naciones, regiones. Los espacios institucionales de la modernidad. Ciudad de México: Fondo de Cultura Económica, 2003.

9 CRUZ, Paulo Márcio. Repensar a democracia. Revista da Faculdade de Direito da UFG Goiânia. V. 33, p. 22-41, 2010.

10 GUÉHENNO, Jean-Marie. El fin de la democracia: la crisis política y las nuevas reglas del juego. Barcelona: Paidós, 1995, p.156.

11 CRUZ, Paulo Márcio; CADEMARTORI, Luiz Henrique. O princípio republicano: aportes para um entendimento sobre o interesse da maioria. Revista Estudos Constitucionais, Hermenêutica e Teoria do Estado (Cursos de Mestrado e Doutorado em Direito - UNISINOS), v. 1, p. 87-96, 2009. SANTOS, Boaventura de Sousa. Globalización y democracia. Bogotá: Palestra, sem data SANTOS, Boaventura de Sousa. Globalización y democracia. p.03. p. 41.

OLLER I SALA, M. Dolors. Un futuro para la democracia: una democracia para la gobernabilidad mundial. Barcelona: Cristianisme i Justicia, 2002, p. 22. SANTOS, Boaventura de Sousa. Globalización y democracia.

17 MÜLLER, Friedrich. Que grau de exclusão social ainda pode ser tolerado por um sistema democrático? Porto Alegre: Unidade Editorial, 2000, p. 32.

18 CRUZ, Paulo Márcio; REAL FERRER, Gabriel. Democracia Econômica, o Estado e a Crise Financeira Mundial. Revista UNOPAR Científica. Ciências Jurídicas e Empresariais, v. 10, p.07, 2009.

19 DEL CABO, Antonio. Constitucionalismo, mundialização e crise del concepto de soberania: algunos efectos en América Latina y Europa. Alicante: Publicaciones Universidad de Alicante, 2000, p.32.

Conforme a obra de ARISTÓTELES. Política. Tradução Mário da Gama Kury. Brasília: UnB, 1985.

21 Na seção O Espírito, da Fenomenologia do Espírito, Hegel analisa o fenômeno político grego, afirmando que este era indissociável da Cidade, e que o homem grego não conseguia conceberse afastado da realidade política. Esta dinâmica Hegel denominou espírito ético, e que tem o início de sua dissolução representada na obra Antígona, de Sófocles, na qual pela primeira vez o cidadão grego se viu na necessidade de escolher entre duas leis: a do Estado (Creonte) e da 
família (Antígona), a nova (Creonte) e a antiga (Antígona), a humana (Creonte) e a divina, representada nos costumes (Antígona). Antes não havia a necessidade de escolha, tamanha era a harmonia do mundo ético.

envolvimento e declínio de uma civilização como significações da formação e decadência daquele povo é um dos argumentos fundamentais da Filosofia da História de Hegel, expresso na obra: HEGEL, G. W. F. A Filosofia da História. Tradução Maria Rodrigues e Hans Harden. Brasília: UnB, 1995.

41 A idéia de crise nas instituições como representando ao fundo um problema existencial dos indivíduos e sociedades também foi tema de reflexões de filósofos existencialistas e psicólogos humanistas do século XX. Entre eles, pode ser citado Rollo May, que defende que o momento conturbado das primeiras décadas daquele século (Crise de 1929, duas Guerras Mundiais, etc.) escondia na verdade o vazio existencial das pessoas. MAY, Rollo. O homem a procura de si mesmo. 23. ed. Petrópolis: Vozes, 1996. BONAVIDES, Paulo. Teoria constitucional da democracia participativa. São Paulo: Malheiros, 2001 , p. 51. SANTOS, Boaventura de Sousa. Pela mão de Alice: o social e o político na pós-modernidade. São Paulo: Cortez, 1995, p. 271.

CHOMSKY, Noam; DIETERICH, Heinz. A sociedade global: educação, mercado e democracia. Blumenau: FURB, 1999, p. 27 e seguintes.

BILBENY, Norbert. Política sin estado. p.169.

BILBENY, Norbert. Política sin estado. p.201.

MOLAS, Isidre. Por un nuevo pacto social. Barcelona: Mediterrânea, 2004, p. 46.

GUÉHENNO, Jean-Marie. El fin de la democracia: la crisis política y las nuevas reglas del juego. p. 32.

MÜLLER, Friedrich. Que grau de exclusão social ainda pode ser tolerado por um sistema democrático? p. 43.

MÜLLER, Friedrich. Que grau de exclusão social ainda pode ser tolerado por um sistema democrático? p. 58.

MOUFFE, Chantal. O regresso do político. Tradução Ana Cecília Simões. Lisboa: Gradiva, 1996, p.27. 
BECK, Ulrich. Qué es la globalización: falácias del globalismo, respuestas a la globalización. Barcelona: Paidós, 2004, p. 93.

CRUZ, Paulo Márcio; BODNAR, Zenildo. La Transnacionalidad y la Emergencia del Estado y del Derecho Transnacionales. Revista vLex. Barcelona, v. 4, p. 12, 2009. BOCKENFORDE, Ernest Wolfgang. Estudios sobre el estado de derecho y la democracia. Madrid: Trotta, 2000, p.151.

55 BILBENY, Norbert. Política sin estado. p.11.

56 Sobre isso ver: CRUZ, Paulo Márcio. Soberania e superação democrática do estado constitucional moderno. Revista Pensar - UNIFOR, Fortaleza, v. 12, p. 107-119, 2007.

60 KAUL, Inge; GRUNBERG, Isabelle; STERN, Marc A. La cooperación internacional en el siglo XXI. Oxford: University Press, 2001, p. 81.

61 O Poder Transnacional é aquele representado pela globalização - a boa e a ruim - que foi alavancada, principalmente, pela atual modelo de economia, comércio, finanças e comunicações desterritorializadas e desreguladas. ATORI, Giovanni. La democracia despues del comunismo. p.130-131

CRUZ, Paulo Márcio; REAL FERRER, Gabriel. Democracia Econômica o Estado e a Crise Financeira Mundial. p. 03. JÁUREGUI, Gurutz. La democracia planetária. p.14.

BECK, Ulrich. La sociedad del riesgo global: amor, violencia y guerra. p. 129.

SANTOS, Boaventura de Sousa. Globalización y democracia.

FELIX TEZANOS, José et alii. La democracia post-liberal. Madrid: Sistema, 1996, p.13.

CRUZ, Paulo Márcio; BODNAR, Zenildo. La Transnacionalidad y la Emergencia del Estado y del Derecho Transnacionales. p. 08.

ECCLESHALL, Robert et alii. Ideologías políticas. p.160.

SANTOS, Boaventura de Sousa. Globalización y democracia.

CRUZ, Paulo Márcio. Repensar a democracia. p. 11.

A idéia de formação da Sociedade em consonância ao desenvolvimento das instituições já era um dos temas fundamentais de Jaeger na sua obra Paideia, na qual aborda o processo espiritual e histórico de formação do homem grego. No percurso grego desenvolvem-se o Direito, o Estado, a ideia de ética, não há como separar o indivíduo da instituição, aquela somente se desenvolve mediante a ação do primeiro, como leciona Werner Jaeger, na obra Paidéia. Além disso, também na passagem do mundo medieval para o mundo moderno viu-se a formação humana como condição fundamental para o processo de construção do Direito e das instituições em geral, conforme a obra Formação do pensamento jurídico moderno, de Michel Villey.

73 Na história da filosofia, as grandes transformações na idéia de Estado eram tratadas não apenas como modificações institucionais, mas, sobretudo, como a vontade histórica da Sociedade naquele período. Exemplo disso é a obra Linhas Fundamentais da Filosofia do Direito de Hegel, na qual aborda a formação do indivíduo como essencial para a construção do Estado Moderno.

74 SANTOS, Boaventura de Sousa. Pela mão de Alice: o social e o político na pós-modernidade. p. 276.

75 FÉLIX TEZANOS, José et alii. La democracia post-liberal. Texto de Goran Therbon, denominado Más allá de la Ciudadania: Democracia post-liberal o liberalismo postdemocrático? p. 56.

\section{REFERÊNCIAS}

AYUSO TORRES, Miguel. Después del Levitán? Sobre el estado y su signo. Madrid: Dykinson, 1998.

BECK, Ulrich. Qué es la globalización? Falacias del globalismo, respuestas a la globalización. Barcelona: Paidós, 2004.

. La sociedad del riesgo global: amor, violencia y guerra. 2. ed. Madrid: Siglo $\mathrm{XXI}, 2006$. 
BERGALLI, Roberto; RESTA, Eligio. Soberania: un princípio que se derrumba. Barcelona: Paidós, 1996.

BILBENY, Norbert. Política sin estado. Barcelona: Ariel, 1998.

BOCKENFORDE, Ernest Wolfgang. Estudios sobre el estado de derecho y la democracia. Madrid: Trotta, 2000.

BONAVIDES, Paulo. Teoria constitucional da democracia participativa. São Paulo: Malheiros, 2001.

CADEMARTORI, Daniela Mesquita Lutchuk de. Limites e possibilidades de uma cidadania transnacional: uma apreensão histórico-conceitual, in CRUZ, Paulo Marcio; STELZER, Joana (Org.). Direito e Transnacionalidade. Curitiba: Juruá, 2010.

CARRO FERNÁNDEZ-VALMAYOR, Juan Carlos. A doutrina clássica alemã sobre a personalidade jurídica do Estado. Notas de uma releitura. Livro em homenagem a Manuel Francisco Clavero Arévalo, t. I, Madrid: Civitas, 1994.

CHOMSKY, Noam; DIETERICH, Heinz. A sociedade global: educação, mercado e democracia. Blumenau: FURB, 1999.

CRUZ, Paulo Márcio; CADEMARTORI, Luiz Henrique. O princípio republicano: aportes para um entendimento sobre o interesse da maioria. Revista Estudos Constitucionais, Hermenêutica e Teoria do Estado - RECHTD, Novo Hamburgo, $\mathrm{n}$. 1, v. 1, p. 87-96, jan/jun. 2009.

. Repensar a Democracia. Revista jurídica FURB. Blumenau, v. 13, n. 25, p. 03-23, jan/jun. 2009.

; REAL FERRER, Gabriel. A Democracia Econômica, o Estado e a Crise Financeira Mundial. Revista UNOPAR Científica. Ciências Jurídicas e Empresariais. Londrina, v. 10, mar. 2009.

; BODNAR, Zenildo. La Transnacionalidad y la Emergencia del Estado y del Derecho Transnacionales. Revista V-Lex (Online), v. 4, 2009.

DANICH, Victor Alberto. Paradigmas da globalização. A Notícia, Joinville, 05 abr. 2003, Opinião, p. 09.

DEL CABO, Antonio. Constitucionalismo, mundialização e crise del concepto de soberania: alguns efectos em América Latina y e Europa. Alicante: Publicaciones Universidad de Alicante, 2000.

DUVERGER, Maurice. La democrácia sin el pueblo. Madrid: Ariel, 1980.

ECCLESHALL, Robert et alii. Ideologías políticas. Madrid: Tecnos, 1998. 
FELIX TEZANOS, José et al. La democracia post-liberal. Madrid: Editorial Sistema, 1996.

GUÉHENNO, Jean-Marie. El fin de la democracia: la crisis política y lãs nuevas reglas del juego. Barcelona: Paidós, 1995.

HELLER, Hermann. Escritos políticos. Madrid: Alianza Universidad, 1985.

JÁUREGUI, Gurutz. La democracia planetária. Oviedo: Ediciones Nobel, 2000.

KAUL, Inge; GRUNBERG, Isabelle; STERN, Marc A. La cooperación internacional en el siglo XXI. Edición en español, Oxford: University Press, México, 2001.

MIGLINO, Arnaldo. Democracia não é apenas procedimento. Curitiba: Juruá, 2006.

MOLAS, Isidre. Por um nuevo pacto social. Barcelona: Ediciones Mediterrânea. 2004.

MOUFFE, Chantal. O regresso do político. Trad. Ana C. Simões. Lisboa: Gradiva, 1996.

MÜLLER, Friedrich. Que grau de exclusão social ainda pode ser tolerado por um sistema democrático? Porto Alegre: Unidade Editorial, 2000.

NINO, Carlos Santiago. La constitución de la democracia deliberativa. Barcelona: GEDISA, 1997.

OLLER I SALA, M. Dolors. Un futuro para la democracia: una democracia para la gobernabilidad mundial. Barcelona: Cristianismo I Justícia, 2002.

PIPITONE, Ugo, Ciudades, Naciones, Regiones. Los espacios institucionales de la modernidad. Fondo de Cultura Económica, Ciudad de México, 2003.

REAL FERRER, Gabriel. La solidaridad en el Derecho Administrativo. Revista de Administración Pública. Alicante: n. 161, p. 123-179, mayo-ago. 2003.

RIFKIN, Jeremy. La civilización empática. Jornal El País. Madrid: 19 mar. 2010, p. 29.

ROUSSEAU, Jean Jaques. O contrato social: princípios de direito político. Trad. Antônio P. Machado. Rio de Janeiro: Ediouro, 19[ ] ].

SANTOS, Boaventura de Sousa. Globalización y democracia. Bogotá: Palestra, sem data. $\overline{\text { Cortez, }} 1995$.

Pela mão de Alice: o social e o político na pós-modernidade. São Paulo: SARTORI, Giovanni. La democracia después del comunismo. Madrid: Alianza, 1993. 
STELZER, Joana; CRUZ, Paulo Marcio. (Org.). Direito e Transnacionalidade. Curitiba: Juruá, 2010.

TEZANOS, José Félix et al. La democracia post-liberal. Madrid: Editorial Sistema,1996.

TOMAS CARPI, Juan Antonio. Poder, mercado y estado en el capitalismo maduro. Valência: Tirant lo blanch, 1992.

VILLASANTE, Tomás R. Las democracia participativas. Madrid: Ediciones HOAC, 2003.

WOLKMER, Antonio Carlos. Ideologia, Estado e Direito. 4 ed. São Paulo: RT, 2003.

YOUNG, Oran R. Teoria do regime e a busca de governança global. In: VARELLA, Marcelo D.; BARROS-PLATIAU, Ana F. Proteção Internacional do Meio Ambiente, Brasília: Unitar, UniCEUB e UniB , 2009.

Recebido para publicação: 03/12/2010

Aceito para publicação: 23/12/2010 